\title{
Judge, Jury, Magistrate and Soldier: Rethinking Law and Authority in Late Eighteenth-Century Ireland
}

\author{
by KATHLEEN S. MURPHY*
}

\section{INTRODUCTION}

The key to understanding law and authority in late eighteenth-century Ireland lies in extraordinary cases. Some historians have dismissed the political trials of reformers and activists as unrepresentative of the "typical" processes of the Irish judicial system. They argue that the majority of Irishmen in the eighteenth century did not believe that their society was particularly violent and that the disenfranchised Catholic majority fared as well as its Protestant counterpart before the law. Criminals were caught, charged by a grand jury composed of local men, and tried by a jury before any sentence was carried out. From constables to judges of the assizes, Ireland retained the institutional forms characteristic of the English system. These historians argue that the majority of cases, in which strict adherence to legal procedure was carried out in the spirit of a "self-policing society," overshadows the few exceptions. However, these extraordinary cases, which dealt not with common criminals, but with reformers advocating constitutional and social change, demonstrate that when the system was under the greatest strain, commitment to English ideals broke down. ${ }^{1}$

The external parallels between the Irish and English systems obscured fundamental differences, differences that corresponded to Ireland's different political and legal reality. The history of Ireland, with its centuries of unrest and rebellion, and with its social divisions along lines corresponding to economic and religious differences, precluded English legal traditions from being transplanted without alteration. The political climate of late eighteenth-century Ireland was one of mounting tension. The beginning of the eighteenth century was marked by a period of relative peace and stability. However, by the middle of the century, popular protests, like the Whiteboys violence in the $1760 \mathrm{~s}$, demanded economic and political change, but seemed to government officials and local gentry to promise only chaos. 2 During the last few decades of the eighteenth century, new manifestations of popular protest emerged

*Graduate student in history at Johns Hopkins University, Baltimore, Maryland.

1. S.J. Connolly, Religion, Law and Power: The Making of Protestant Ireland (Oxford: Clarendon Press, 1992), esp. 220-233; Neal Garnham, Courts, Crime and the Criminal Law in Ireland, 1692-1760 (Dublin: Irish Academic Press, 1996), esp. 66, 253-9, 266, 277.

2. Connolly, 218-9; Jim Smyth, The Men of No Property: Irish Radicals and Popular Politics in the Late Eighteenth-Century (Dublin: Gill and Macmillan, 1992), 14-36. 
coincident with intellectual movements for reform. Groups like the United Irishmen advocated constitutional reform inspired by revolutions abroad and the ideals of the Enlightenment. ${ }^{3}$ Meanwhile the British government became paranoid about unruly Catholic subjects within and threatening Catholic enemies abroad. These fears seemed justified when in 1798 a small French force landing on the west of Ireland was joined by Irish Catholics hoping to overthrow English rule. ${ }^{4}$ Under pressure from local gentry, who themselves were under the strain of these domestic and international threats, the Dublin government repressed the nascent reform movement, which ultimately only further radicalized it. The extraordinary cases in which the ideals of English rule by law were sacrificed must been seen from within this milieu of unrest, uncertainty, and fear.

Centuries before these disturbances, English policy towards Ireland established the idea that Ireland was different. In spite of the Anglo-Irish gentry's claim to the contrary, Ireland was not a sister kingdom of England, and had no inherent claims to the tradition of the English legal constitution. Nicholas Canny argued that this distinction dated to the reign of Queen Elizabeth, when the imminent threat of Spain justified treating Ireland differently than Elizabeth's "principal dominion." In Ireland, he argued, "authority far in excess of anything that was customary in England was vested in the appointees of the Crown... also the government was willing to countenance military action against the native population far more readily than it would have done at home."5 The precedent set in the sixteenth century to treat Ireland differently-to subvert the ideals of the English constitution when circumstances demanded-continued to shape the course of Irish history in the eighteenth century.

The most striking difference between England and Ireland in the eighteenth century was the three million Catholics who were excluded by law from the political nation. Rooted in the English Reformation, the penal code barred Catholics from interreligious marriages, practicing law, and holding government positions. This collection of statutes limited property and inheritance rights, outlawed Catholic ordinaries, and severely restricted the practice of Catholicism. Unsurprisingly, the penal code also excluded the majority of the population from the ranks of the magistracy and the legal profession. Legislation aimed at bogus converts passed in 1733 and 1734, went so far as to debar lawyers married to Catholics and forbid men who converted from Catholicism to serve as justices of the peace. ${ }^{6}$ After a century under the penal code, by 1778 Catholics

3. Connolly, 218-21. R.B. McDowell, Irish Public Opinion. (London: Faher and Faher, 1944), passim.; Stanley Palmer, Police and Protest in England and Ireland: 1780-1850 (Cambridge: Cambridge University Press, 1988), 104-5.

4. Connolly, 248-50.

5. Nicholas Canny, Kingdom and Colony: Ireland in the Atlantic World, 1560-I800 (Baltimore: John Hopkins, 1988), 29.

6. Maureen Wall, Penal Laws, 1691-1760: Church and State from the Treaty of Limerick to the Accession of George III (Dundalk: Dundalgan Press, 1961), 11-12; Connolly, 291. 
owned only five percent of the total land in Ireland. ${ }^{7}$ In the last decades of the eighteenth century, the penal code was increasingly relaxed and ultimately repealed by the time of the Act of Union in 1800. However, even into the first decades of the nineteenth century, the "self-policing" institutions of British rule rarely included the Catholic majority.

That the institutions of law and authority of eighteenth-century Ireland were based on an English model is undeniable. For some historians, the importation of the ideals of an English self-policing society itself maintained peace in this turbulent country. 8 They note that like the English system, the civil law enforcement authority was divided into a magistracy consisting of justices of the peace, sheriffs, constables and watchmen. Such an explanation overlooks, however, how the suspension of these ideals in extraordinary cases, the presence of the military, and the exclusion on religious rather than economic grounds of three-fourths of the population from the upper magistracy and judicial benches dramatically altered the Irish situation.

The actors involved in these institutions fall into one of three categories: judges and juries, magistrates, and the military. The first two categories retained many of the forms and ideals of their English counterparts-trial by jury, indictment by a grand jury, local men enforcing local law, and the English common law tradition. Religious and economic qualifications for judges, jurors, and most magistrates restricted the pool of potential participants in this "self-policing" society to a minority of the population. Additionally, a general trend towards centralization and service-at-will created an infrastructure of influence that established avenues through which the Dublin government was directly linked to local institutions of law and authority. As for the third category, its very presence would have aroused the Englishman's fear of the threat to liberty posed by a standing army. ${ }^{9}$ These seemingly slight, yet fundamental, differences between English and Irish situations of law and authority created a system with the capability to ignore the ideals on which it was based for the perceived exigencies of the moment.

\section{THE JUDGE AND JURY: “PILLARS” OF SOCIETY}

Like their English counterparts, Irishmen believed that the cornerstone of their inherited liberty as British subjects was the right to a trial by jury. According to Edward Bullingbroke, writing in 1766, a jury provided "that happy way of trial" which was "one of the pillars" of the British Empire. 10 This "happy way" distributed responsibility for the execution of law across multiple layers of society. Elites in the Irish Parliament and the

7. Smyth, 13.

8. Connolly, 198. Palmer, passim.

9. John Trenchard, "Free thoughts concerning officers," London, 1698, passim.

10. E[dward] Bullingbroke, Duty and Authority, quoted in Garnham, 133 (Originally published Dublin, 1766, 55-62.) 
king's representatives in Dublin Castle devised the laws, sat as grand jurors, and presided over trials as judges, but cobblers, candle-makers, and shopkeepers were entrusted with the responsibility for applying these laws as petty jurors. The centralized nature of this system, which gave the Lord Lieutenant personal control over the appointments of most of these positions, established the infrastructure of influence. The less public aspects of this infrastructure, namely crown witnesses and informers, offered the crown even greater potential.

The grand jury, as both the first stage in the progress of a case through the court system and as the body charged with overseeing local administration, followed its English model of local men supervising the maintenance of order on a local basis. According to Arthur Young, traveling in Ireland in 1776, grand juries were composed primarily of "resident gentlemen, their agents, clergy and respectable tenantry." 11 These men, or members of their families, would continue to serve on the grand jury for years.

The grand jury lists for County Tipperary demonstrate this pattern of grand jury domination by a few families. Butlers, Mathews, Pritties, and Minchins, titled families whose daughters brought dowries ranging from 3,000 to 10,000 pounds, and who owned extensive lands in Tipperary generating annual rental incomes of 10,000 pounds, are frequent entries on the county's grand jury lists. 12 These were the leading men of the county, related through marriage and blood, and serving repeatedly together. Henry Prittie, the first Lord Dunalley and a Member of Parliament from 1768 to 1790 , served on the spring 1782 and March 1796 grand juries. His cousin, John Bayly served on the summer 1777 grand jury, and his brother-in-law and fellow Member of Parliament, Peter Holmes, served on the spring 1783 grand jury. 13 Although the exact family relationships between all the grand jurors are impossible to determine, the County Tipperary lists frequently repeat the same surnames. In some cases, men with the same family name seem to stagger their service, appearing on jury lists in alternating years. Nicholas Mansergh served on the spring 1777, spring 1778, summer 1781, spring 1783, and March 1796 grand juries, while Richard Mansergh served on the summer 1777 and summer 1780 grand juries. Families like the Pritties and the Manserghs were the natural leaders of the eighteenth century, men of the highest social and economic stature who were expected to act out of public spiritedness, but who also had a vested interest in maintaining societal order.

An extended period of service on the grand jury appears to have been the norm. Of the eighty-nine grand jurors listed in the surviving County Tipperary grand jury lists from the late eighteenth century, only

11. Arthur Young, A Tour in Ireland: 1776-1779, vol. II, ed. A.W. Hulton (original edition 1780, photolithographic facsimile, 1970), 57.

12. Thomas Power, "Genealogies," Land, Politics, and Society in Eighteenth-Century Tipperary (Oxford: Clarendon Press, 1993), 331-5; MS 7331 "Grand Jury Lists for Counties Tipperary and Limerick: 1765-1800," National Library of Ireland, passim.

13. Power, passim. MS 7331. 
30 served just a single term. 14 More commonly, jurors reappeared on grand jury lists three or four times. Samuel Allegh appeared for the first time in the spring 1778 list and continued on each of the six subsequent lists. Table 1 illustrates this pattern of repetitive service.

TABLE 115

\begin{tabular}{lccccccc}
\hline \multicolumn{7}{c}{ County Tipperary Grand Jury Lists: } \\
\multicolumn{1}{l}{ Total Number of Terms Served by Each Member of the Grand Jury } \\
\hline & 1 & 2 & 3 & 4 & 5 & 6 & 7 \\
& term & terms & terms & terms & terms & terms & terms \\
\hline Summer 1780 & 7 & 3 & 5 & 3 & 3 & 0 & 1 \\
Summer 1781 & 2 & 4 & 5 & 5 & 4 & 1 & 1 \\
\hline
\end{tabular}

While grand juries were the domain of the upper echelons of society, petit juries were composed primarily of men from the middling ranks. The fundamental qualification for petty jury service was a man's status as a "freeholder," an economic distinction. By the eighteenth century, however, such economic distinctions had social and religious dimensions. Under Irish legislation (1756), "freeholders" owned property worth at least ten pounds, or, if Protestant, leaseholders of a minimum income of fifteen pounds per annum and fifteen years of continuous tenure. The requirement that jurors own their own land or be long-standing Protestant leaseholders excluded, by some estimates, over three-fourths of the Irish population from participating in Bullingbroke's "pillar" of the kingdom. 16 Catholics who owned their own land could serve on juries, but decades of penal legislation meant only a tiny fraction of Irish Catholics owned the land they worked, which excluded them by practice, if not by legislation, from jury duty. 17

The limited jury lists available support the idea that petty jurors were primarily successful men engaged in trade who had accumulated the necessary ten pounds of property. 18 When available jury lists from trials held

14. Only lists from Lent 1776, spring and summer 1777 , spring 1778 , summer 1780 , summer 1781, spring and summer 1782, spring 1783 and March 1796 survive in MS 7331. Other undated lists included in MS7331 although believed to date to this period, were disregarded for this paper.

15. MS 7331, NLI, passim. The lists from 1780 and 1781 represent the middle years of the available records.

16. Garnham, 260. Although he downplays its significance, Garnham raises the interesting possibility that in addition to economic and religious exclusion, a language barrier might have further alienated the native Irish from the British legal system. Until the mid-nineteenth century, the majority of the Irish population spoke Irish, which the judicial system attempted to accommodate by sending interpreters with judges on their assizes.

17. In 1688 Catholics owned twenty-two percent of the land in Ireland, in 1703 only fourteen percent, and by 1778 five percent. Smyth, 13.

18. The bombing of the Public Records Office in Dublin in 1922 destroyed official jury lists from this period. Lists for individual cases, particularly famous cases involving national heroes like A.H. Rowan and Dr. Drennan, survive in other sources including published accounts of famous trials and collections of personal papers. 
in Dublin are compared with Dublin Directory and The Gentleman's Almanack's lists of Dublin residents, between 67 and 92 percent of jurors are merchants or artisans. The jury of the high-profile 1794 trial of Dr. Drennan, a United Irishman accused of seditious libel for an editorial criticizing the government and urging the Irish to demand reform, contained eleven merchants. Sir John Trail, the twelfth member and the only titled juror, served as foreman. 19 The jury panel of Archibald H. Rowan, accused of libel for his part in the same editorial, contained a baronet and member of the House of Commons, a lawyer of high social status, another member of Commons and the "serjeant at arms" of the House of Lords. The remaining eight members of the jury were all merchants dealing in industries ranging from banking to land survey. 20 The next year, eleven merchants and one alderman (who served as foreman) heard the trial of the less famous Reverend Jackson.21 Although members of the poorest classes of Irish society are absent altogether from jury lists, members of the highest classes appear only occasionally. In the only case examined for this paper with a substantial number of jurors of the highest classes, the defendant himself (Rowan) was a member of the Protestant gentry. The majority of men deciding these cases of political importance were members of the middle-class and almost exclusively Protestant.

While Catholics with property could qualify to serve on a jury, even they were not welcome deliberating a case involving loyalty to the state. Statutes in both England and Ireland prohibited Catholics from serving on juries in cases dealing with enlistment of British men in foreign armies.22 Additionally, Irish statutes specifically prohibited Catholics from serving on jury panels for penal code infractions or on civil cases involving a dispute between a Protestant and a Catholic. The legal code was amended in 1793 to allow Catholics to sit on all jury panels and to join the lower ranks of the bar and magistracy. 23 Even after this change, jury composition could be dramatically influenced by crown-appointed sheriffs who determined the pool of perspective jurors.

In effect these statutes divided trials into two categories - those of a

19. John Philpot Curran. The Speeches of the Right Honorable John Philpot Curran, ed. Thomas Davis (Dublin: James Duffy, 1853). Although Speeches has an overtly national prejudice, it remains a valuable source for both the rhetoric of reform and for the detailed introduction of each case, which usually includes copies of the indictments, jury lists and background to the case; Samuel Watson, Dublin Directory, (Dublin: Watson, 1797), passim., John Stewart, Gentleman's and Citizen's Almanack (Dublin: Thomas and John Stewart, 1797), passim.

20. Curran, Speeches, 155; Watson and Steward, passim.

21. Thomas MacNevin, ed, Lives and Trials of Archibald Hamilton Rowan...and other Eminent Irishmen (Dublin: James Duffy, 1846), 204-5. Although these cases were extraordinary cases of huge political importance, there is no indication the economic breakdown of other cases differed greatly. Neal Garnham's study of assize records and statutes from the first half of the eighteenth-century indicates a similar demographic breakdown of juries.

22. Garnham, 136, 144.

23. Nicholas Canny, "Ascendancy and Union," in R.F. Foster, ed. The Oxford Illustrated History of lreland (Oxford: Oxford University Press, 1989), 180. 
universally acknowledged criminal nature and those that reflected or challenged the particular Irish political and legal systems. Cases that held the potential to split public opinion on religious and social lines generally maintained these lines in the composition of the jury. Catholics could and did sit on panels for murder and larceny. They could not, however, sit in judgment of a man accused of treason for serving in the army of Catholic Spain or France, an offense targeting Irish Catholics. In cases of murder or theft, no issue of the submerged social fissures was raised, and thus economic qualifications sufficed. When a case directly reflected such fissures, jury selection became political, and political lines in Ireland were usually drawn on religious grounds. Irrespective of the facts of the case, explicit exclusion of Catholics from such juries reinforced social fissures by declaring that even the most Anglicized Catholic could not be trusted to uphold the interests of the government. 24

If the jury was intended to represent the voice of the people in the courtroom, then Irish judges embodied the authority of the king. Support for for the crown administration could earn appointments to the bench, but the government's influence continued after appointment. In the notes on the Irish House of Commons, prepared in $\mathbf{1 7 6 9}$ for Viceroy Townsend, Richard Power was noted to be a government supporter and a lawyer who "wants to be a judge." Supporting the government's programs in Parliament could earn a Member of Parliament a seat on the bench.25 Until 1782 Irish judges held their places at the king's pleasure, leaving them directly accountable to the Dublin government. ${ }^{26}$ Assize judges were direct extensions of the Dublin government. Any open positions on the as size courts were offered to the king's councilors in order of descending seniority. Such a policy allowed the same men who argued for the state in Dublin courts to hear cases in the rest of Ireland. Judges and administration perceived their jobs as mutually supportive. When Justice William Smith was considering a request for mercy, he consulted with Major Sirr, Dublin town-major and government operator, about the possible political leanings of the defendant. 27 Whether traveling the country on assize or hearing a case in Dublin, avenues of influence remained open for the Dublin administration to exploit.

The trial judge's instructions to the jury established parameters for the verdict it would reach. Points of law were within the discretion of the judge because "every action to be tried by a jury, must be founded in principles of law; of that, however, the court only can determine."28 Only in

24. The issue of upholding government interests is, of course, not purely one of religious affiliation. Many prominent reformers were Protestant and members of the highest classes.

25. D. Large, "The Irish House of Commons in 1769," Irish Historical Studies 11 , (1958-9), 39, passim.

26. William Holdsworth, A History of English Law, vol. XI (London: Methuen, 1938), 26.

27. MS 218: Original Documents Illustrative of Secret Service Money Dealings, "Sirr Papers," March 30, 1801. Pearse Street Library, Dublin City Library.

28. Curran, Speeches, 143. 
cases of libel was the jury "not bound to go by the opinion of the court to jury," although judges certainly made their opinion known in their instructions to the jury. 29 A judge could direct the jury how it should find. In the 1770 Lessee of North v. Crofton case, "the judge having been of this opinion [that the defendant's deed did not defeat the plaintiff's title] charged the jury to find for the plaintiff, and a verdict was accordingly had for him." 30 With the possible exception of libel cases, Irish judges' prerogatives to determine all points of law translated into a formidable influence over trial outcomes.

Ideally trial judges would "be judge of law and leave facts to Juries," but if the jury decided to go against the instructions of the judge, the judge could simply overturn their verdict and proclaim his own.31 Judges had the power to both overturn verdicts in their entirety or to simply adjust the restitution awarded. During the 1771 trial of Dennis $v$. Warren, the jury found for plaintiff but "in delivering their verdict, declined giving the plaintiff any costs; and although frequently pressed by the Court to find costs, yet absolutely refused to find any." Unhappy with the jury's decision, the plaintiff applied to court to tax the costs "as if costs had been found by the jury." Predictably the defendant objected, saying that a judge's authority to award costs only applied when the jury inadvertently failed to find costs and the court only had the power to set aside verdicts, not to alter them. The court however, "determined that the costs were of course, consequential to damages; and therefore ordered the officer to tax them, as if found by the jury. 32 Empowered with the king's judicial authority, Irish judges could circumvent those decisions that they thought were inappropriate.

Although charges of packed and biased juries surrounded famous political trials like those of Orr and Drennan, in the vast majority of cases juries upheld the rule of law. On the 13th of May 1788, a Mr. Griffith and some friends were nearby when Alderman Exshaw was attempting to disperse a riot. According to the bill of indictment, these men spoke "opprobrious, malicious, and contemptuous words of a justice of the peace in the execution of his office." 33 Griffith was convicted but the verdict was overturned on appeal because of the imprecise and ambiguous wording of the bill of indictment. Lord Chief Justice Earlsfort wrote that "whatever the defendant's degree of guilt may have been; how strongly soever it may have been proved, if he is intitled to a legal advantage from a literal flaw, God forbid he should not have the benefit of it." 34

29. MacNevin, 121 .

30. John, K.C. Wallice, Reports of Select Cases Argued and Determined in the High Court of Chancery in Ireland. Principally in the time of Lord Lifford, ed. James Lyne (Dublin: Hodges and Smith, 1839), 41.

31. "Free Citizen," The Office and Power of a Judge in Ireland (Dublin, 1756), 5.

32. Wallis, 103-4.

33. Vernon and Scriven, 612.

34. Ibid., 632. 
Even in extraordinary cases dealing with challenges to the government's authority, juries often extended "a legal advantage." United Irishman Dr. Drennan was charged in 1794 with seditious libel for the authorship and publication of a United Irish paper which made inflammatory demands for the formation of extra-legal associations to advocate for "universal emancipation, and representative legislature." 35 Defense attorney Curran objected to the presence of Sir John Trail on the jury on the grounds that Trail had previously expressed an opinion wishing for the conviction of Drennan. Curran's objection was overruled. When the jury returned from their deliberations, Trail as foreman, addressed the court, denouncing Drennan's involvement with the United Irishmen but saying "they [the jury] regret at seeing a criminal they cannot reach, and guilt which they cannot punish," announcing a verdict of not guilty. ${ }^{36}$ This case illustrates that there was no consistent policy of using the legal system as a tool of oppression. For Drennan's jury, procedure and evidence trumped prejudice. But as we shall see with Drennan's co-conspirator, A.H. Rowan, the government had the resources at its disposal to shift this balance to its advantage.

In the majority of cases, judges and juries in Irish courtrooms reflected the English common law tradition. The common criminal proceeded through the legal system from a grand jury composed of the leading men of his locality to a trial by a jury composed of merchants and artisans who owned sufficient property. What is exceptional about the Irish process is not that only a minority were full members of the political nation, but that common religious and political interests characterized this minority. This same distinction reoccurs in all but the lowest ranks of the men charged with overseeing the preliminary steps of the judicial process.

\section{THE MAGISTRATES: MEN CARRYING OUT THE LAW}

Like its English parallel, the ideal of a self-policing Irish society was embodied in a hierarchical magistracy. At the very top of the civil establishment sat the Lord Lieutenant in Dublin, the king's personal representative in Ireland, at whose pleasure magistrates and judges alike served. Under the centralized administrative system, the Lord Lieutenant, with his advisors and ministers, appointed magistrates, determined whether the military would be sent to assist local authorities, granted pardons, and rewarded service to the government with pensions and positions within the administration. ${ }^{37}$ Such extensive authority, particularly when it could be felt even at the lowest levels, provided the means through which crown influence could be felt.

At the next rung of the hierarchy, sat justices of the peace, for many

35. Curran, Speeches, 154-5. This is the same document discussed below in regards to A.H. Rowan.

36. Ibid., 205.

37. Garnham, passim. 
of whom wealth brought them to prominence both in local law-enforcement and in Dublin politics. Justices of the peace not only assisted and oversaw the inferior magistracy in apprehending criminals, carrying out court orders, preventing riots, and generally trying to preserve the peace, but they also could pronounce judgments on legal disputes in the interim between assizes. In the 1770 Stewart $v$. Stewart case, a dispute over land possession in County Armagh was settled by three local justices of the peace rather than wait for it to be settled by a judge during the next assize. The justices of the peace heard arguments against the defendant who took forcible possession of land and awarded restitution to the plaintiff. 38 In such routine cases of property rights or inheritance, the justices of the peace fulfilled the basic judicial role and remained true to the ideal of a self-policing society.

These men who wielded such judicial influence over their neighbors generally wielded similar influence outside of their official capacity. Appointed by the Lord Chancellor in Dublin, justices of the peace were usually the largest landowners in the locality or the man personally recommended by such magnates to the Lord Chancellor. All the men listed in the Dublin Directory's 1797 list of magistrates of chief towns were either clergy in the Church of Ireland (the established Protestant church), lawyers, or were listed as "gentlemen." The town of Baltinglass offered a typical example. The Directory listed the "Honorable and Rev. F. P. Stratford" as sovereign, "William King, Esq." as deputy, "Edward Westby, Esq." as recorder and "Thomas Allen, gent." as town clerk. ${ }^{39}$ Similarly, the Gentleman's and Citizen's Almanack's list of justices of peace for each county contained a sizable numbers of peers and members of Parliament. The 1797 list for County Kilkenny included an earl, a viscount, four baronets, a knight and 52 others including figures prominent on the national political stage such as Henry Flood and George Dunbar, both members of the House of Commons. 40 The same men who dominated the social, political and economic affairs of each county landlords and the local gentry, embodied legal authority in the office of justice of the peace.

While local law was invested in the person of the justice of the peace, courts vigilantly attempted to retain control over the exercise of authority at the local level. In King v. Dillon, the justices of the King's Bench ruled that a justice of the peace was incapable of determining the validity of testimony he collected. The case concerned Henrietta Burkett, a 12-year-old girl who was raped and later died from her injuries after giving her testimony under oath to Alderman Barton of Dublin. The question before the court was whether Henrietta sufficiently understood the nature of the oath and thus whether Barton should be allowed to read her testimony before the jury. The court ruled two to one that, "When the whole attention of a superior Court is necessary, it is improper to rely upon the

38. Wallis, 97.

39. Watson, 126.

40. Stewart, 90 . 
judgment of any inferior magistrate, especially as uncertainty might arise from their apprehension, often not strictly to be supported by law." 41 This protection of the court's jurisdiction is part of a general trend towards greater centralized control of the institutions of law.

More so than the justices of the peace, sheriffs would have been familiar figures for the average Irishman. The sheriff's duty to collect revenue for the crown and carry out verdicts returned during assizes meant that the sheriff was a highly visible figure in the local community. In addition to these responsibilities, the sheriff supervised the election of members of the Irish Parliament guarded prisoners, and tended to judges while they were on assizes. Similar to justices of the peace, sheriffs heard minor cases in what was known as the "turn-court."

Although the local sheriff was the most visible figure of British authority in rural Ireland, the authority he commanded appears to often have been insufficient to fulfill his duties. One of the most frequent topics of the Kilmainham Papers, a collection of letters written by the commander of the British military in Ireland to civil authorities in Dublin, featured local magistrates asking for military assistance to carry out mundane tasks such as transporting criminals and attending assizes, even in times of relative peace and stability. One such letter noted the request of magistrates in Athy requiring soldiers "assisting the High Sheriff, or his sub-Sheriff, in guarding the Gaol of that place, as also a party to assist in conducting the prisoners from Athy to Naas." 42 The pool of men qualified and willing to serve as sheriff was not sufficient to create a civil law enforcement presence capable of preserving order. The self-policing English model often remained an elusive ideal for most of Ireland.

It was not as a policing force, but as an assistant to the court, that the local sheriff exerted the most profound influence over the fate of his neighbors. Before each jury trial the local sheriff returned the pool from which the jury was selected. Consequently this responsibility often landed sheriffs in the middle of polemical attacks on the government's control of criminal trials through the power of the sheriff to return prospective jurors. Thomas MacNevin, editor of Lives and Trials of Archibald Hamilton Rowan ... and other Eminent Irishmen, argued that trial by jury was no blessing to Ireland but through the agency of "corrupt sheriffs, by terrorism and other unrighteous means, [became] an instrument of oppression." 43 Appointed annually by the Lord Lieutenant in consultation with the chief judges and the county magistrates, sheriffs kept their jobs from year to year by remaining in the favor of the local gentry and the Dublin government. ${ }^{44}$ The Lord Lieutenant's control of shrievalty appointments ensured that even local magistracy remained under centralized control and

41. Wallis, 9.

42. MS 1011, Kilmainham Papers, National Library of Ireland, Vol. 11, April 6, 1791, 49. For other examples see vols. 7, 8, 10 and 12, passim.

43. MacNevin, 495.

44. Garnham, 94. 
subject to constant review.

The government's indirect control of jury composition became especially controversial during trials of opponents of the government. Peter Finnerty, publisher of the only newspaper independent of the government, was charged in 1797 with "false, wicked, malicious and seditious libel" for an editorial that criticized the Lord Lieutenant for not pardoning William Orr although the convicting jury had recommended mercy. 45 Arguing for Finnerty, Curran noted that the same man who was the target of the bitter editorial attack, the Lord Lieutenant, approved the appointment of the sheriff who in turn selected the members of the jury:

You know, and we know, upon what occasion you have come, and by whom you have been chosen; you are come to try an accusation professedly brought forward by the state, chosen by a sheriff who is appointed by our accuser. ${ }^{46}$

After arguing that the editorial reflected the facts of the affidavits and the popular outcry against Orr's execution, Curran appealed to the conscience of the jury "to refute and to punish so vile an expectation by the integrity of your verdict." 47 Unfortunately for Finnerty, however, he was found guilty and sentenced to stand in the pollory for two hours, pay a 20-pound fine, and serve two years imprisonment. Additionally, the last remaining independent newspaper became government property.

Charges of biased sheriffs returning packed juries were not confined to the circus-like atmosphere surrounding United Irish trials. A similar instance can be gleaned from James Lyne's collection of important Irish legal decisions, based on manuscript notes of John Wallis, a lawyer practicing in the late eighteenth-century Ireland. In Mayne v. Mayne a sheriff was accused of bias, and a new jury was ordered to be returned. Before the trial in 1773, the "usual jury process for trial ... [was] directed to the Sheriff of the County Fermanagh," but on the trial day a challenge was entered of a partial sheriff. The challenge being found good, the "succeeding sheriff" was ordered by the court to return a new jury panel. The defendant, against whom the jury found, later appealed to the Exchequer Chamber that the verdict should have been overturned because the sheriff returned the second jury, instead of the coroner. Mayne v. Mayne indicates that while checks on the system operated, the often did not imperfectly. Although the trial judge recognized and accepted the defendant's challenge of partiality, the return of the second jury by the same partial sheriff undermined the efficacy of challenging the jury in the first place. 48

According to the Irish judge Gorges Howard, by 1766 most shrieval responsibilities, especially more mundane ones such as revenue collection

45. Curran, Speeches, 276-7.

46. Ibid., 279.

47. Ibid. 280.

48. Wallis, 151-3. On appeal the Exchequer Chamber affirmed the original verdict, but on procedural grounds. The justices argued that the defendant should have challenged the second jury at the time of the trial and that the nature of the basis "does not arise from any permanent cause, such as relationship in blood." 
and jury return, became the role of sub-sheriffs. 49 By law sheriffs could designate responsibilities to sub-sheriffs for whom there were no religious requirements. When a high sheriff returned the jury for highly political trials, such as those of United Irishmen, defense lawyers and defendants often argued this was only so the government could better control the composition of the jury returned. Archibald Rowan, accused of libel against the government, believed that Sheriff Giffard's personal return of the jury only further emphasized the lengths to which the government would go in order to secure an unjust conviction. 50

At the bottom level of the magisterial hierarchy, constables and watchmen carried out the mundane and disagreeable tasks necessary to maintain order. The duties of constables ranged from extinguishing fires to whipping convicted criminals to enforcing observance of the Sabbath.51 In a role similar to a modern security guard, the watch had little authority of its own but patrolled the parish during the night to preserve the peace and could detain suspicious persons whom they presented to the magistrates in the morning. 52

Members of the watch and constabulary were more likely to be of the same social class than of the same religion. According to 1720 handbook for constables, constables received no pay for their year of service, and all men paying hearth tax were required to serve on the watch or the constabulary. Those who could afford it paid a substitute to fulfill their obligation. These jobs quickly began to be associated with lower social classes who would fulfill another man's civic duty for a fee. 53 Based on constables' exemption from oaths of abjuration, allegiance, and against transubstantiation, Neal Garnham suggested that the majority of constables were Catholic. 54 Only at the very lowest levels of the magistracy, where the authority entrusted to each individual was the smallest, was class and not religion the deciding qualification. Constables and watchmen comprised the bottom rungs of a hierarchical and centralized magistracy that retained strong ties to the crown administration.

The magistracy's potential for crown influence attracted the attention of reformers as an example of what was wrong with the Irish government. Throughout pamphlets arguing for or against the Act of Union, defending the United Irishmen, or calling for Parliamentary reform, appeared charges of corruption and ineptitude in the Irish magistracy. Testifying before the Secret Committees of the Houses of Lords and Commons about the causes of the Rising of 1798, United Irishman Dr. McNevin argued that, "the insurrection was occasioned by

49. Quoted in Garnham, 95.

50. Archibald H. Rowan, The Autobiography of Archibald Hamilton Rowan, ed. William H. Drummond (Shannon: Irish University Press, 1840), 189; MacNevin, 172.

51. Bullingbroke, 55-62.

52. $6 \mathrm{Gl} \mathrm{cl0.}$

53. Gamham, $27 ; 6$ George I c 10

54. Garnham, 29. 
the houseburnings, the whipping to exhort confessions, the torture of various kinds, the free quarters, and the murders committed upon the people by the magistrates and the army." 55 Historians of the following generation shared the belief that a corrupt magistracy was a tool of British oppression. Thomas Davis, editor of The Speeches of the Right Honorable John Philpot Curran (1853), noted in the introduction to the transcript of Finnerty's trial that the government was "armed with a full code of coercion and a large army and unscrupulous agents to support it." 56 Although these charges and the accompanying vignettes are decidedly propagandistic, other sources confirm that the magistracy was not only unrepresentative of the majority of the population, but also that the people often had reason not to trust the institutions of law.

Reformers and members of the United Irishmen characterized the magistracy as a violent, honorless, and corrupt band of criminals. According to the overtly nationalist memoirs of Miles Byrne, an exiled United Irishman, justices of the peace selectively enforced the law, so alienating the majority of the population that rebellion was inevitable. According to Byrne, "many of the low-bred magistrates availed themselves of the martial law, to prove their vast devotion to the government, by persecuting, and often torturing the inoffensive country people." 57 The case of Hevey v. Major Sirr (1802) parallels Byrne's description of magistrates proving their dedication to the government through extra-legal means. Hevey, a former member of the yeomanry corps, had testified against a witness for the crown, and the accused was subsequently acquitted. In response, Major Sirr, the Dublin town-major, sheriff, and government operator arrested Hevey and had him tried by court martial and sentenced to hang to "teach him how to meddle with his people." The Lord Lieutenant released Hevey upon reviewing the case, but when Sirr and Hevey next met, Sirr threatened and eventually imprisoned Hevey a second time. 58 Such incidents suggest that there may have been some truth in reformers' accusations. 59

As a judge serving the British government in Ireland after the Act of Union, Leonard MacNally could hardly be considered a nationalist. But the very existence of his book, The Justice of the Peace for Ireland: Containing the Authorities and Duties of that Office (1808), supported the reformers' case against the magistracy. MacNally wrote his guidebook in an attempt to rectify the "ignorance in jurisprudence daily exhibited by the proceedings of magistrates." The book was intended not as a criticism

55. Memoire: Or a Detailed Statement of the Origin and Progress of the Irish Union Delivered to the Irish Government by Messrs Emmell, O'Connor, and McNevin; Together with the Examinations of these Gentlemen Before the Secret Committees of the Houses of Lords and Commons, Dublin 1802 (Joly Collection), National Library of Ireland.

56. Curran, Speeches, 276.

57. Miles Byrne, Memoirs of Miles Byrne, ed. Fanny Byrne. (New York: Gustave Bossange, 1863; reprinted in Shannon: Irish University Press, 1972), 33.

58. Ibid., 384-5.

59. Concise Dictionary of National Biography, vol. 1 (London: Oxford University Press, 1969), 1206. 
of the British presence in Ireland or even of its legal institutions, but as a practical guide to improving the quality of those institutions on the local level. The magisterial responsibilities and the laws outlining them had become so complex that "the powers given to Justices of the Peace create such a variety of business that few care to undertake, and fewer to understand the office." 60 MacNally devoted two volumes and over 600 pages enumerating the qualifications and specific duties of the various magistrates, while providing references to the laws these men would need to be familiar with to perform their duties properly. Like Curran and Rowan, MacNally recognized that many Irish magistrates were inept, ignorant, and incapable policing their society satisfactorily.

Law reports from the late eighteenth century also indicate that the weaknesses of the magistracy were acknowledged problems and did not always go unpunished. The $1776 \mathrm{King} v$. Mocler case found its way into James Lyne's compilation of Irish law cases because of the procedural question it raised over whether a magistrate could be reinstated after misconduct without first giving a full account of his misdeeds. Mocler, a justice of the peace for County Cork, "had been attached for some misconduct in that office; and having lain for some time under that attachment, now applied by petition to the Court to be discharged." 61 Although the justices of the King's Bench ruled that Mocler did not have to give an account of his deeds, thus leaving modern readers with no indication of what got him into trouble in the first place, the statement substantiates the nationalist claims of magisterial misdeeds. Like Mayne v. Mayne, King $v$. Mocler indicates that courts charged with overseeing the activities of the magistracy could punish wayward justices, and attempted to maintain control over the magistracy as a whole. Popular awareness of this bias and corruption fed into the escalating pattern of reprisal and repression.

Contributing to the problem of ineffective, inept, or corrupt sheriffs, the common use of appointment to the magistracy to reward supporters of the government artificially inflated magisterial ranks. Like judgeships, magisterial appointments provided the government with a means of winning support for their programs. Before the House of Commons, Curran said that in one day, twenty-four commissions for Justices of Peace were sent to County Clare. Curran interpreted the unusual and seemingly unnecessary appointment of twenty-four magistrates in one day as indicative of 'jobbing" on the part of the government.62 The personal records of Major Sirr also indicate a substantial practice of awarding government positions to men who had served the government as witnesses, informers, retired military officers, or in some other capacity. ${ }^{63}$ Such magistrates at best were ineffective and at

60. Leonard MacNally, The Justice of the Peace for Ireland: Containing the Authorities and Duties of that Office (Dublin: Fitzpatrick, 1808), v, vi.

61. Wallis, 257-8.

62. Curran, Speeches, 65.

63. MS 218, Gilbert Collection, "Original Documents Illustrative of Secret Service Money Dealing," Pearse Street Library, Dublin City Library. See a more detailed discussion of the "Sirr Papers" below, p. 37. 
worst served the interests of the Dublin government more directly.

The actual number of active magistrates fell far short of the number of men on the government's payroll. The Gilbert manuscript lists just over 2,000 justices of the peace in 1760 but based on the available assize records for the period between 1760 and 1789, Garnham estimates that the number of active magistrates outside of Dublin fell between fourteen and thirty-four percent. ${ }^{4}$ Such a level of inactivity would have left the preservation of peace in a country of over three million people with a turbulent history of unrest in the hands of somewhere between 280 and 690 men. The requirement that justices of the peace be "of the most sufficient knights, esquires and gentlemen of the law," left a small pool from which to draw candidates in a predominately poor and Catholic country. 65 In his 1776 tour through Ireland, Arthur Young noted that two neighboring baronies in the west of Ireland, Killda and Costello, had no justices of the peace. 66 Areas of sparse Protestant settlement, particularly in the west, presented especially difficult areas to preserve order by means of the traditional forms of a self-policing English society.

Irish institutions preserved the forms of the self-policing society, specifically a magistracy divided into descending levels of authority, under the control of local men. What distinguished the Irish situation were the centralized organization of the system and the exclusion of the majority from magisterial ranks on the basis of religious affiliation. The highly centralized organization, part of a more general trend of centralizing power in Dublin, placed extraordinary authority and influence into the hands of the Lord Lieutenant. The exclusion of Catholics from the upper ranks of the magistracy is not significant simply because it excluded the majority of the population-economic requirements would have accomplished the same exclusion. Similar to jury qualifications, the exclusivity of the magistracy reinforced the political dimensions of religious affiliation. On a superficial level the Irish magistracy mirrored its English counterpart-in both, men of the highest social and economic standing held the highest positions within the magistracy. But baronies like Killda and Costello illustrate that when this parallel did not apply--where the leading men were not Protestant-then the barony would go without a justice of the peace rather than trust the position to a Catholic. With the civil establishment so handicapped, the preservation of order required assistance from a source the average Englishman would have found an anathema-the military.

64. Gilbert, MS 34, National Library of Ireland, 181; Garnham, 34.

65. 13 Rich $2 \mathrm{c} 7$, quoted in Leonard, 84.

66. Young, 247. 


\section{THE SOLDIER: GIVING NEEDED ASSISTANCE}

To the average Englishman, a large military force policing its own people was a time-bomb aimed at liberty, just waiting to explode. ${ }^{67}$ For some Irish magistrates and landowners, it was the only way to ensure order and peace. For other Irishmen, however, the military represented the draconian potential of authority and a symbol of continuing unrest. 68 British civil and military authorities, attuned to these highly emotional views of the army, played a constant balancing act-trying to reserve the military for only the gravest emergencies but faced with a civil establishment that could not maintain order unaided. Most of the tasks to which soldiers were assigned were mundane activities like escorting prisoners, guarding jails assisting revenue officials, and accompanying sheriffs on seizures. Constant charges of oppression at the hands of the military appear in nationalist tracts. The records of the military itself suggest that soldiers occasionally crossed the line between law-enforcer and lawbreaker, and that the military often protected them. The Kilmainham Papers evidence constant territorial disputes with civil authorities over procedure and leadership. Although the military provided a needed prop to the civil magisterial authority, its presence embodied a fundamental difference between the reality of Ireland and ideals of a self-policing society.

On the most mundane level the military provided extra manpower to an understaffed magistracy. In addition to assisting sheriffs in the execution of their duties, the military assisted the even more unpopular revenue officers. ${ }^{69}$ The Kilmainham Papers are full of complaints from the revenue office accusing the military of not helping enough as they went around the country collecting for the crown. In one instance the Surveyor of Excise complained that troops stationed on a "Man of War" refused to assist revenue officers. The Surveyor insisted that commanders be instructed "that the Army of the Man of War may give their aid to the Revenue Officers [illegible] when called upon." 70 The issue was of great enough importance that seven months earlier the Lord Lieutenant drew up instructions detailing the expected conduct of the military when assisting the revenue service. ${ }^{71}$ The military presence in Ireland allowed the crown to perform unpopular offices of government, like collecting revenues or carrying out seizure orders, in spite of potential popular resistance.

The very presence of soldiers within a town was believed by many civil authorities to prevent disturbances. Military commanders regularly received requests from magistrates and local gentry for soldiers to be stationed in their locality. A Mr. Birmingham, justice of the peace for the

67. Trenchard, passim.

68. Kilmainham Papers, passim.

69. For more on the relationship between the military and the sheriffs see above pages 19-20 and Kilmainham Papers, vol. 7, 53, \& 161; vol. 9, 309.

70. MS 1007, Kilmainham Papers, vol. 7, 96, Nov. 1, 1784.

71. Kilmainham Papers, vol. 7, 35, Apr. 12, 1784. 
counties of Mayo and Galway, "required three companies of the garrison of Galway to be Quartered on his estate for the preservation of the peace."72 Although the military commander considered this an "extraordinary request," similar requests were common, and many landowners like a Mr. McNeil of Dundalk, were assigned the troops they requested.73 As the century drew to a close and the unrest preceeding the Rising of 1798 built, the number of requests for a military presence increased. 74 The Rising itself, however, testifies to the eventual inability of the military to guarantee peace as magistrates hoped.

While the assistance of the military to local sheriffs and revenue officers was a necessary component in the preservation of order, it had to be reconciled with the traditional English fear of standing armies. The army had to remain subordinate to the civil authority. Soldiers were assigned to assist the local sheriff, never to perform duties in his stead. 75 The centralized system of authority ensured that the civil government, in the person of the Lord Lieutenant, retained ultimate control over the military. Before troops could be sent to an assize or to assist a magistrate, the Dublin government first had to give approval. This system created a complicated bureaucracy that became the source of numerous disputes over the particulars of the cooperation between civil and military resources.

Repeatedly, arguments between commanders and justices of the peace lead to the military commander writing the Lord Lieutenant asking him to control the magistracy, presumably while the magistrate wrote a similar complaint. According to one commander's complaint, "if those magistrates are permitted to pursue the same line of conduct, it will be impossible to preserve the proper harmony that ought to subsist between the Military and Civil Power."76 Disputes with the civil authorities often centered on the extent to which military commanders were required to obey local magistrates. These complaints and accusations suggest an underlying strain beneath the coordinating military and civil authorities.

The instructions with which the Dublin administration furnished the military in response to these territorial battles established a shared authority between local magistrates and military commanders. In January 1785 military commanders were instructed that, "they should give immediate assistance if they shall be satisfied from the information of the Magistrate that there is a strong probability of the offenders being likely to be found in the places they are supposed to be in." 77 Magistrates retained control

72. MS 1008, Kilmainham Papers, vol. 8, 104, Apr. 7, 1786

73. vol. 11, 80, 162, Oct. 24; Nov. 30, 1792.

74. Kilmainham Papers, vol. 7-12, passim.

75. Although it appears that some magistrates believed differently. One letter to the Lord Lieutenant blames the escape of a prisoner escorted by soldiers on the absence of the sheriff, denouncing magistrates who failed to perform "so essential a part of their duty." Kilmainham Papers, vol. 9, 74, Apr. 17, 1787.

76. Kilmainham Papers, vol. 8, 127, Aug. 19, 1786.

77. Ibid., vol. 7, 130. 
over the responsibility to arrest criminals, but the instruction created a loophole for commanders to refuse assistance. Two years later the military commander wrote to the Lord Lieutenant's secretary, asking him to get the lord judges to determine "how far an officer is authorized in refusing to obey the orders of a magistrate." 78 Although accusations flew on both sides, the generally concerned internal politics. Rather than desiring a check on the use of the military as an auxiliary policing force, these disputes suggest civil authorities favored wider application of these military resources.

The high number of retired soldiers who became police officers created an additional link between military and civil authorities. The infamous Henry Charles Sirr, who kept meticulous records of the government's "secret service money dealings," returned Peter Finnerty's jury, and was the defendant in Hevey v. Sirr, served as town-major of Dublin from 1796 to 1826 after serving in the army from 1778 to 1790.79 When a less familiar group of retired officers expressed interest in becoming part of the police force in the city of Dublin, General Cunningham offered to write a recommendation on their behalf. 80 Most of these men could not help but come to law enforcement, not as "local men" attuned to the needs of their neighbors and locality, but as former soldiers whose primary loyalty was the preservation of order through the government they had already served.

Although requests for military assistance never slowed, neither did charges of oppression and criminality. Advocators of reform like Curran and Finnerty referred to the military as a tool of the government, a means of repressing the press and controlling legitimately motivated popular demands for change. 81 Evidence of violence and excess by soldiers appeared in the military's own records. In a few of the worst cases, soldiers seem to be common criminals-starting riots and murdering and raping women. A letter dated June 12, 1784, reported that main and castle guards "commanded a violent riot and committed several outrages in Copper Ally...that a great part of the Castle guard between three and four o'clock on Sunday $13^{\text {th }}$ instant, were concerned in using a woman very ill and threatened a Constable of the Watch." 82 Although the writer noted that an inquiry into the "outrage" was ordered, no mention of the outcome of this outrage or the punishment the soldiers received exists in the Kilmainham Papers. Soldiers like those involved in the Copper Ally incidents could only encourage the idea that the military was in Ireland to oppress rather than to protect.

The use of military discipline rather than the civil judicial system circumvented the normal channels of justice and created a double

78. Ibid., vol. 9, 190, Dec. 10, 1787

79. Concise Dictionary of National Biography, 1206.

80. Kilmainham Papers, vol. 8, 97, Mar. 22, 1786.

81. MacNevin, 513.

82. Kilmainham Papers, vol. 7, 57. 
standard in which some law-enforcers were not subject to the very laws they imposed upon others. After a soldier was accused of murder, military authorities petitioned the Lord Lieutenant to drop the civil case and allow it to be handled by the military's own disciplinary system.83 In a similar case, soldiers broke into the Kinsale jail to free two comrades who had been confined for assaulting a magistrate while he attempted to quell a riot. The military inquiry determined that the original two men had been injured during the riot and the magistrate would not allow the men to be released on bail to receive treatment. Only this endangerment of the soldiers' lives, according to the military's account, motivated the soldiers to break into the jail. The court martial cleared the soldiers of all charges, except for the original charge of obstructing a magistrate. 84 The very process of removing the case from civil authority undermined the idea of a subordinate military.

The attempt to subordinate the army to the civil government reflects the English distrust of a standing army. Centralized control, with the Lord Lieutenant in charge of both the army and the civil establishment, helped to maintain this balance. Throughout the letters of the Kilmainham Papers, military and civil leaders expressed concern over retaining the forms of the English self-policing society. Although soldiers performed necessary functions of law-enforcement for which the civil establishment was not adequately equipped, it remained a symbol of the government's formidable potential for oppression.

\section{THE SYSTEM AT WORK: THE FAR REACH OF DUBLIN CASTLE}

Beyond the official actors of the judicial and peacekeeping institutions, the Dublin government had additional resources with which to affect the systems of law and order. Slight differences between Irish and English statutes-the government's prerogative to change the location of a trial, the strain put on juries, and the practice of paying witnesses and informers - created control for Dublin Castle even beyond that built into the highly centralized structure of the system. Evidence of official manipulation of the judicial system for cases other than those of highly political trials, like those of the United Irishmen, is rare. Special resources and judicial practices ensured, however, that if needed, the government could exert considerable influence.

According to many contemporaries, one of the government's favorite ways to get rid of troublesome citizens was to let them sit in jail for a few months, or in some cases even years. Arthur O'Connor, M.P., claimed in his "Addresses to the Electors of the County of Antrim" that, "the present Ministers and their accomplices have destroyed every vestige

83. Ibid., vol. 8,10 , June 13,1785 . The military commander was probably correct when he argued that his soldiers could never receive a fair trial at the hands of a local jury.

84. Ibid., vol. 8, 144-47, 152, 158-61, Sept. 4, 1786. 
of Election by Martial Law, and by imprisoning your Candidate upon false pretenses, on the eve of a general election," presumably because of his reformist political leanings. 85 Rowan told a more disturbing story in his autobiography. According to Rowan, after one of his servants refused to fabricate charges against him:

he having resisted, it was thought that something might be forced from him by fear. Accordingly he was apprehended on a warrant of high treason, and was told by the person who took him, that he had but one way to save his life, which was to swear against me. He was kept in gaol five months under this charge; and while in confinement, they attempted to cajole him into the king's service. When by law he became entitled to be discharged, or have proceedings preferred against him, the charge of high treason was withdrawn, and an indictment found against him for a misdemeanor. 86

While neither O'Connor or Rowan were the most impartial commentators on the government, the sheer repetition of these charges adds to their credibility. Additionally, the absence of a Habeas Corpus Act until 1781 and its immediate suspension during the troubled last few years of the century, added a legal means to pursue this very same end. 87

Another seemingly slight difference in the Irish legal code compared to its English counterpart reduced the minimum number of witnesses necessary to obtain a treason conviction. In England a treason conviction required two witnesses giving evidence to overt acts. As the Reverend William Jackson learned in April 1795, Irish law only required a single witness who was not required to testify to overt acts. Once again defense attorney, Curran attempted to use the comparison with English law in Jackson's favor:

Curran: That is the settled law of the neighboring kingdom...because far from am I from thinking, that we have not the blessing of living under the same sanction of laws...that the proof, which in England would not wound the man, still here deprive him of his life.

Lord Chief Justice Clonmel: Do you mean to argue that the statute of William is in force in Ireland?

Curran: No, my lord; not that the statute of William is in force-but I mean to argue, that the necessity of two witnesses in the case of treason is as strong here as in England.88

Jackson's case illustrated that although England served as the model for Irish law, slight differences in the Irish code gave the Dublin government much greater power.

Even without obtaining a conviction, the government could manipulate the system to make litigation expensive and inconvenient for enemies of the government. After the proprietors of Belfast's Northern Star, published by United Irishmen, were arrested for seditious publications, they

85. Arthur O'Connor, State of Ireland (London, 1798), iii.

86. Rowan, 187.

87. Holdsworth, 26; Curran, Speeches, 254.

88. Curran, Speeches, 214. Jackson was found guilty of treason by the testimony of a single witness but committed suicide before he could be sentenced. 
petitioned Belfast's sovereign, arguing that "as the proprietors were numerous, and all, less or more, engaged in mercantile pursuits, it would be at once a cruel and unnecessary exercise of power to hurry them away eighty-two miles to enter a recognizance in Dublin." Accordingly, the sovereign wrote to Dublin to receive authority to take bail, but his request was denied, forcing the thirteen defendants to travel to Dublin to post their bail. Later, the attorney general took the unusual step of moving "as a matter of right for a trial at bar" a case originating in County Antrim to Dublin. Jury, sheriffs, and defendants alike had to travel to Dublin and find lodgings. 89 According to Thomas Davis, editor of the account of the trial, "the fees alone for obtaining copies of the informations, stamps and fees of office, and license for Mr. Curran to plead against the crown, have been little short of ONE HUNDRED POUNDS!!!"90 Although the proprietors, except for the printer, were found not guilty, the time and money involved was likely a sufficient message for the government to send.91

The government could exert a less official influence over trials through crown witnesses and informers. Describing the state of Ireland during Finnerty's trial, Curran said:

I speak of what your own eyes have seen, day after day, during the course of this commission, from the box where you are now sitting; the number of horrid miscreants, who acknowledged, upon their oaths, that they had come from the seat of government-from the very chambers of the Castle-where they had been worked upon, by the fear of death and the hope of compensation, to give evidence against their fellows. 92

The personal papers of Major Sirr suggest that "the hope of compensation" was often fulfilled. Men who "served the government" were rewarded with money, clothes, and even passage to America.93 Sirr's June 12, 1798 entry recorded fifty pounds "for Mr. Dutton, by desire of Lord Castlereagh," the acting chief secretary of Ireland and remembered for a "most lavish corruption."94 For others pardon, rather than payment, motivated their service to the government. J. Bird, involved with the 1798 Rising, provided the government with a detailed description of his knowledge of the rising in an attempt "by any means tend to expiate the offenses I was rash enough to commit." 95 Curran was more direct characterizing the motivation for Mr. Carey, a witness against Dr. Drennan, "as to the influence of his situation on his evidence, what did he say?-he was not sure of a pardon, but he hoped for one."96 Similarly, Thomas O'Hara,

89. Ibid., 206-7.

90. Ibid., 207, emphasis in original.

91. Ibid., 210.

92. Ibid., 297.

93. MS 218, "Sirr Papers," passim.

94. MS 218, "Sirr Papers"; W.E.H. Lecky, A History of Ireland in the Eighteenth Century, ed. L.P. Curtis (Chicago: University of Chicago Press, 1972).

95. MS 218, "Sirr Papers."

96. Curran, Speeches, 202. 
another prisoner, attempted to gain his freedom by promising Sirr he would serve the government after his release:

I am confident that the smallest application your Honor interference would liberate me...you shall find in me an acquisition that will make an atonement difficult to compensate my former proceedings...I would be of the most essential Service to you now in the city more than you can at present imagine. 97

In all, between August 21, 1797 and September 30, 1801, over 38,000 pounds were "applied in detecting treasonable conspiracies, pursuant to the provisions of the Civil List Act of 1793" which, for the most part, amounted to paying off informers and the infamous "Major's Men" who cultivated such contacts.98 Although the 1793 act gave legal authority to the existence of the Major's Men, their activities provided the government with control over the judicial system against the spirit, if not the law, of the statute.

The well-documented trial of the government against Archibald Hamilton Rowan demonstrates various mechanisms at the disposal of the Dublin government to affect the outcome of the trial. Rowan, a member of the Protestant gentry and secretary to the United Irishmen, was accused of publishing a "certain false, wicked, malicious, scandalous, and seditious libel" calling for the Volunteers of Ireland to meet in each parish and elect delegates to an extra-legal Protestant convention to demand parliamentary reform. 99

The origin of the case against Rowan was itself unusual. A grand jury never reviewed the charges against him to determine whether it represented a prima facie case. Instead the charges were entered ex officio, without a formal presentment and upon hearsay. Curran commented that while such a proceeding in itself was not unjust,

If the charge had no cause of dreading the light--if it was likely to find the sanction of a grand jury-it is not easy to account why it deserted the more usual, the more popular, and the more constitutional mode, and preferred to come forward in the ungracious form of an ex-officio information. 100

According to Curran, had Rowan's case been sent to a grand jury, it "would have been tried at the next commission; but a speedy trial was not the wish of his prosecutors." 101 Once the charges were made, no trial date was set, and a series of delays followed. According to Rowan, the crown prosecutors thrice withdrew the information entered against him on pretenses of errors within the document itself in order to delay the trial. 102

During the intervening year John Giffard, "notoriously under the influence, and even in the pay of the government," replaced Henry Hutton

97. MS 218, "Sirr Papers."

98. MS 218, "Sirr Papers," Item 104, "100 Original Documents, Letters, and Memoranda in Relation to 'Secret Services"' in Original Documents Illustrative of Secret Service Money Dealings. Pearse Street Library, Dublin City Library.

99. Curran, Speeches, 153-155.

100. Ibid., 157.

101. Ibid., 157.

102. Rowan, 186. 
as sheriff. 103 Rowan believed that his suspicions about Giffard were confirmed when the sheriff himself returned the entire jury, instead of following the standard practice in Dublin, which delegated that responsibility to a sub-sheriff. 104 For reformers like Curran, Gifford exemplified the corruption of the government through "placemen." In addition to his shrieval duties, Gifford was editor of a governmental newspaper and wrote numerous editorials opposing the United Irishmen and against Rowan personally. Although Curran argued that Gifford's crown offices should have precluded him from returning Rowan's jury, Lord Justice Clonmel ruled that if holding an office under the crown and being in the militia were to be disqualifications, it would disqualify every sheriff in Ireland. 105 Thus a political and personal opponent of Rowan returned his jury. A jury which, according to Curran, was not "of his own choice, which the law of England allows, but which ours refuses; collected in that box by a person certainly no friend to Mr. Rowan-certainly not very deeply interested in giving him a very impartial jury." 106 Curran' s accusation appeared vindicated when, after the trial, an affidavit was entered swearing that before the trial one member of the jury said, "Ireland would never be quiet until Hamilton Rowan and Napper Tandy were hanged."107

The timing of the key crown witness's army commission, paid by a member of the Dublin administration, adds to the picture of government corruption painted by the Sirr Papers. 108 Based primarily on this testimony, Lord Chief Justice Clonmel "charged the jury violently against Mr. Rowan," who was subsequently found guilty, despite testimony by crown character witnesses who swore they would "hesitate to believe him [the crown's main witness]."109

While Curran may have been justified when he said Rowan was "hunted down like a victim" by the legal system, the Dublin government was not in the business of man hunting. 110 Rowan's trial is the type of extraordinary case some historians argue should be put aside. While it is far from exemplifying the "typical" operation of the institutions of law and authority in Ireland, it demonstrates the extreme to which the Dublin government could go, even if it rarely did. Placemen, prejudiced jurors, trial delays, ex officio presentments, and crown witnesses provided the Dublin government with extraordinary leverage over the institutions of law and authority.

103. Ibid. 187.

104. MacNevin, 204.

105. MacNevin, 157-8.

106. Curran, Speeches, 181.

107. Ibid., 189

108. Ibid., 179.

109. Ibid., 182-189. Rowan was sentenced to a 500-pound fine and two years imprisonment, which he avoided by escaping to France.

110. Ibid, 158. 


\section{ENGLISH LAW: IRELAND'S "PARTIAL STEP-DAME"}

Contemporary commentators on Irish law recognized its particular relationship with its English parallel. While some authors celebrated "our boasted constitution under which Irishmen enjoy inestimable advantages over all other nations," others added a wry footnote, "even if she sometimes behaved like a "partial step-dame."' 111 The Irish criminal code itself was not intended to be a replica of the English code. While it shared the heritage of English common law, as a separate kingdom Ireland had her own laws passed by the Irish Parliament, approved by the Irish Privy Council and ministers in London. Additionally, Ireland was subject to Westminster statutes extended to or specifically passed for Ireland.

This different constitutional arrangement was part of the legacy of difference Canny described. Of much greater importance were the social divisions within the society, in which rich and poor generally coincided with Protestant and Catholic, landowner and tenant, justice of the peace and watchman, self-policing and policed. Catholics obviously were not uniformly landless and powerless; they were, however, much more likely to be so.

Irish institutions for maintaining peace were not arbitrary perversions of English traditions. While Rowan's trial illustrates the extensive power at the disposal of the government, there is no evidence that the government concerned itself with jury packing or cultivating crown witnesses for the trial of the average criminal. Charges of the grossest perversions of official prerogative coincide with times of great stress and unrest. The peace which characterized the first half of the eighteenth century was gradually eroded in the following decades by agrarian secret societies, popular support for the American and French Revolutions, economic hardships, and demands for political reform by groups such as the United Irishmen. In response, Viceroy Earl Fitzwilliam pushed through the relaxation of the penal code in 1793. The trials of Rowan, Drennan, and the proprietors of the Northern Star occurred during the height of England's war with France in the 1790s. Four years later, in the legendary "Rising of '98" martial law was declared in March, Wexford rebelled in May, and a small French force landed in Killala in August. Fitzwilliam's liberalization could not check the tide of discontent. Worse, it exacerbated the fears of the local Protestant gentry living in the midst of this unrest who saw evidence of an international papist plot behind the turbulence. These leading local men increasingly advocated a temporary suspension of the rule of law when they called upon the military to preserve order and encouraged a severe crackdown on reformers such as Rowan and Orr.112

The cycle of repression and reprisal further radicalized this "drift towards crisis" in the last decade of the eighteenth century. Although

111. "A letter to a noble lord," 1770 , "The question of previous consent discussed," 1756 , and "Patriotic queries," 1755, quoted in McDowell, 24, 21.

112. Canny, "Ascendancy and Union," 179-182. 
demoralized and threatened, the Protestant gentry still controlled the institutions of law and order. Draconian repression at the hands of magistrates, soldiers, and individuals; described by Byrne, O'Connor, and Curran; only fed into this atmosphere of resentment and unrest. In these extraordinary times, the infrastructure of influence became pivotal. Undeniably the institutions of order were staffed predominately by government supporters. Magistrates and judges were likely elite, wealthy, and Protestant. If not necessarily elite or wealthy, juries and sheriffs were mostly Protestant and were certainly subject to a substantial degree of government control. These men, however, served not as English conquerors looking to subdue the pagan Irish, but as Irishmen attempting to maintain order in a society approaching crisis.

In extraordinary cases like Rowan's, the rule of law was sacrificed for what was perceived as the interest of preserving order. Only in these extraordinary cases do the fundamental differences with the English tradition become apparent. As historians have well documented, in the vast majority of criminal cases the rule of law prevailed, regardless of social, economic or religious distinctions. In the exceptional case that concerned politics more than criminality, however, religion became more important than economics. Those rare Catholics who possessed the requisite property to sit on juries, found themselves excluded in such cases. In these cases the ability of the government to influence sheriffs and judges, offer incentives to witnesses, intimidate other witnesses, and manipulate the venue of the trial itself had a profound outcome. In these exceptions, not in the rule, are found most striking aspects of the Irish legal system.

Eighteenth-century Ireland was not a totalitarian regime looking to stifle all resistance, but rather a government torn by the contradiction of ideals and reality. On the one hand were the ancient liberties and rights of Englishmen and traditional fears of standing armies and highly centralized government, but on the other hand magistrates and administrators alike increasingly could not maintain order while upholding these ideals. Law and authority in late eighteenth-century Ireland reveals not a system of absolute power, but one spiraling out of control. The turmoil at the turn of the century, to which authorities increasingly responded by sacrificing the ideals of a self-policing society, set the stage for the agrarian protests and demands for Catholic Emancipation which characterized the next halfcentury of English rule in Ireland. 